\title{
Relationship between Employee Personality and Job Performance: Based on the mediating effect of organizational trust and work values
}

\author{
Huili Ye \\ School of management, Wuhan University of Technology, Wuhan 430000, China.
}

790733110@whut.edu.cn

Keywords: Employee personality, work values, organizational trust, job performance.

\begin{abstract}
Human resource is the most basic and most important resource among the various resources of enterprise, and it is also one of core competitiveness in the enterprise. With the continuous development of economy and technology, the human resource management of enterprise has become an important subject. In order to improve the job performance, to maintain the long-term development of the enterprise, more and more researchers begin to pay attention to the relationship between employee personality and job performance. This article explains the impact of personality traits on job performance. This article regards the employees work values and organizational trust as intervening variables, and establish a new conceptual model for personality and work performance. The existing research study only considered staff internal factors as intermediary variables, or only considered the external environment factors as intermediary variables, this article makes employees work values as internal mediation variable and organizational trust as external mediation variable, which will make up for the deficiency of existing research, meanwhile, this article provides a methodology for human resource recruitment, training and development in the enterprise.
\end{abstract}

\section{Introduction}

One of the core proposition of modern human resources management is to solve the problem of the relationship between the people and organizations more effectively and improve job performance. As a result of the increasingly competition, more and more enterprises realize that the company's competitiveness mainly come from a group of high-quality staff, because they are the lifeblood of enterprise and the key to improve enterprise job performance. As an employee's unique characteristic, it is an important issue for researchers to determine whether the personality traits of employees are related to the work performance.

Over the past century, the relationship of employee personality and job performance, management performance has always been hot research at psychology, management, organizational behavior. Understanding the relationship between employee personality and job performance of enterprise employees has the following advantages: first, when recruiting in the enterprise, they can understand the employee's personality by the talent assessment, so as to choose the right talents for jobs; Second, the result of employees' personality can be used to predict the achievement that employees can get in the actual work. Before the 1980s, the development of all kinds of personality theory is plural, and failed to achieve a unification. At that time, the study about predicting job performance by employee personality is contradictory. Until the emergence of the five factor model of personality, which changed the situation[1].The existing studies have shown that The existing studies have shown that the personality traits of individual employees affect the performance of individual employees as a bridge[2].Third, when people and organization develop to a certain stage, they will develop slowly or stagnant, at this time, managers can find out problems, defects and deficiencies through the analysis of employee personality and take measures to improve staff quality and ability, which achieve the sustainable development.

Although researchers have done some research about how employees' personality influence their job performance, but the way to affect job performance and its mechanism for employees' personality is still controversial, which remains to be explored. In order to explain the relationship between 
employee personality and job performance, this article combine the internal influencing factors and external influencing factors at the same time, and put forward new hypothesis on the basis of existing research.

\section{Literature Review}

\subsection{Personality Traits.}

Personality traits are the constant response of individual to different environments and maintain a high degree of stability over a long period of time. Therefore, personality is defined as chronic and unchanged tendency of reaction to others behavior or external environment [3]. Some influential personality theories are Mr. Potter trait theory [4], Cattell 16 personality factors theory [5] and five factor model of personality and so on. These theories are inherent relationship, the latter study and change factors on the basis of the earlier and eventually finished. This article has organized the development of personality theory, which was shown in Table1:

Table1 The development of personality theory

\begin{tabular}{|c|c|c|}
\hline $\begin{array}{c}\text { The } \\
\text { researchers }\end{array}$ & $\begin{array}{c}\text { Year of } \\
\text { study }\end{array}$ & content \\
\hline Allport & 1937 & Cardinal trait, central trait, secondary trait. \\
\hline Cattell & 1949 & $\begin{array}{r}\text { Warmth, intellect, emotional, stability, aggressiveness, liveliness, dutifulness, social } \\
\text { assertiveness, sensitivity, paranoia, abstractness, introversion, anxiety, open } \\
\text { mindedness, independence, perfectionism, tension. }\end{array}$ \\
\hline Eysenck & 1947 & $\begin{array}{r}\text { Personality is the sum of the behavior patterns of the actual manifestation of the people, } \\
\text { including intelligence, character, temperament and constitution. }\end{array}$ \\
\hline $\begin{array}{c}\text { Tupes \& } \\
\text { Christal }\end{array}$ & 1961 & Energetic, cheerful, reliable, stable, gentle. \\
\hline Rotter & 1966 & Internal controlling personality and external controlling personality. \\
\hline $\begin{array}{c}\text { Costa \& } \\
\text { McCrae }\end{array}$ & 1985 & Extroversion, agreeableness, openness, conscientiousness, neuroticism. \\
\hline
\end{tabular}

Nowadays, there are all kinds of personality model, the research about five factor model of personality and Cattell 16 personality factors model are systematic, but the personality of internal control and external control personality model study is less, this article will focus on the personality of internal control and external control which came up by Rotter [6].

Table2 The development of work values

\begin{tabular}{|c|c|c|}
\hline The researchers & Year of study & content \\
\hline Super & 1970 & $\begin{array}{c}\text { Work values are the work qualities that individuals pursue. It } \\
\text { expresses the intrinsic need of individuals. }\end{array}$ \\
\hline Manhardt & 1972 & $\begin{array}{c}\text { Work values have three dimensions: comfort and safety, ability } \\
\text { and growth, status and independence. }\end{array}$ \\
\hline Taylor \& Thompson & 1976 & $\begin{array}{c}\text { The four dimensions of work values: security environment, } \\
\text { intrinsic motivation, self-expression, pride which comes from work } \\
\text { and extrinsic motivation. }\end{array}$ \\
\hline Elizur & 1984 & $\begin{array}{c}\text { Work values are the intrinsic motivation to influence external } \\
\text { action directly. }\end{array}$ \\
\hline $\begin{array}{c}\text { Elizur,Borg, Hunt } \\
\text { \&Beck }\end{array}$ & 1991 & $\begin{array}{c}\text { Work values have three dimensions of structural features: } \\
\text { cognition (status, feedback and state), emotions (recognition, } \\
\text { respect and interaction) and tools (wages, benefits, and security). } \\
\text { Intrinsic value, extrinsic value, social value, prestige value. }\end{array}$ \\
\hline Surkiss & 1992 & $\begin{array}{c}\text { Three dimensions of work values: standards, hobbies, and } \\
\text { cognition. }\end{array}$ \\
\hline Robbins & 1996 & $\begin{array}{c}\text { The performance of individual values in work is the goal that people } \\
\text { achieve through work }\end{array}$ \\
\hline Schwartz & 1999 &
\end{tabular}




\subsection{Work Values.}

The research of work values comes from the discussion of the concept of values. The earliest is the concept of the Super, Super consider from demand level, he thinks that the work values is the inner need of individuals and the pursuit of quality or attribute when working, and is the individual's pursuit of work-related goals [7]. Then scholars put forward a lot of definition of work values, which probably can be summarized as two kinds of orientation, one is defined from the meeting demand, another is from the psychological characteristics, such as hobbies [8]. Although the researchers define the concept of work values from different aspects, its connotation is consistent, summarized as Table2:

In conclusion, the research about the definition and structure of work values are fruitful, although there are some differences in definition, the interpretation of work values is from two aspects. One is the inner demand of employees, another is focusing on the judgment standard. This article discusses the work values from Manhardt (1972): work values has three dimensions: comfortable and safe, ability and growth, status and independence [9].

\subsection{Organizational Trust.}

Trust is the expectation, assumption, or belief that the future actions of others will be beneficial to oneself, or at least not harmful to oneself. As a positive attitude towards others or social entity [10]. Trust is in the central position of the various relationships or contracts, guiding people's attitudes and behaviors. Studies of trust can be divided into two factions, some scholars emphasized the social and moral content, other scholars focus on the strategy and calculation in trust, and the ideas of the other scholars, are usually the compromise of them. Although the nature of trust is still debated, the understanding of trust is shared in some other ways. Several different definitions of organizational trust are sorted out as Table3:

Table3 The development of organizational trust

\begin{tabular}{|c|c|c|}
\hline The researchers & Year of study & content \\
\hline Nyhan \& Mariowe & 1977 & $\begin{array}{l}\text { Divide organizational trust into organizational trust and } \\
\text { system trust, and interpersonal trust and system trust. }\end{array}$ \\
\hline Remple, Holmes \& Mar & 1985 & $\begin{array}{l}\text { Organizational trust includes organizational members' trust } \\
\text { in leadership, trust in colleagues, and trust in the organization } \\
\text { as a whole. }\end{array}$ \\
\hline McCauley \& Kuhnert & 1992 & $\begin{array}{c}\text { Divide organizational trust into horizontal trust and vertical } \\
\text { trust. }\end{array}$ \\
\hline Constingan \& Berman & 1998 & $\begin{array}{l}\text { Organizational trust includes the trust of employee to direct } \\
\text { leaders, colleagues, and senior leaders. }\end{array}$ \\
\hline
\end{tabular}

This article tends to divide trust based on the trusted object, and thinks trust in the organization should include trust one and be trusted one. Meanwhile, the object of trust can be established between personal - director, personal-colleagues, personal-organization at the same time. Trust of this research are studied from the above three dimensions.

Table 4 The development of job performance

\begin{tabular}{|c|c|c|}
\hline $\begin{array}{c}\text { The } \\
\text { researchers }\end{array}$ & $\begin{array}{c}\text { Year } \\
\text { of study }\end{array}$ & content \\
\hline Lee & 1985 & Performance is both an act and a result, and the key is to achieve the objective of \\
performance evaluation.
\end{tabular}




\subsection{Job Performance.}

New Performance is one of the focuses of many organizations today, but based on the different perspective, the interpretation of this problem is also different. In the perspective of management, the performance is the desired results in organization. As for the definition of performance, the researchers gave different results, which is shown in Table4:

\section{Hypothesis and Model Construction}

\subsection{Employee Personality and Job Performance}

In 1991, M.R. Barrick and M.K. Mount uses the meta-analysis technology and based on the five factor model of personality, they raised the predictive power of personality on job performance from 0.1 up to 0.2 or so, conscientiousness was increased to 0.31 [11].

Barrick's meta-analysis has changed the bias of low predictability between the employee personality and the job performance, and also made people pay more attention to the relationship between the human factors in the organization and the work performance.

According to Lefcourt (1966), the individuals with internal controlling personality believe that both positive and negative events are the result of their own actions. On the contrary, the individuals with external controlling personality believe that individual predictions have no effect on the consequences of events, the consequences of events are caused by luck, opportunity, and fate [12]. Lefcourt (1972) also found that individuals with internal controlling personality are more likely to pursue achievements, and generate positive solutions when they encounter setbacks, they have less anxiety [13]. For the individuals with external controlling personality, they are more sensitive, anxious and they inclined to concern about the fall of fear rather than a successful achievement, when they encounter setbacks, they also won't take positive actions to solve problems.

Based on the above analysis, this article makes the following hypothesis:

H1a: the internal controlling personality positively affect job performance;

$\mathrm{H} 1 \mathrm{~b}$ : the external controlling personality negatively affect job performance.

\subsection{Employee Personality, Work Values and Organizational Trust}

Work values are those that transcend specific situations and guide individuals to choose and evaluate the behaves which are in relation to their work. And it points to different concepts and beliefs about the importance of the status and behavior that the individual wants to achieve [14]. Raja (2004) found that extroverted employees chose to maintain a relatively long-term and stable relationship with the organization [15]. Costa and McCrae (1992) argued that people with low emotional stability tend to produce depressed emotions such as fear, anger and sadness [16]. Furnham (2015) studied the relationship between personality traits and work values based on the five factor model of personality, the study found that conscientiousness in the five factors had a positive predictive effect on the working relationship, and the extroversion had positive predictive effects on the inner work values. Openness in the five factor is negatively correlated with economic conditions and working conditions [17]. Schneider and Dachler (1978) believe that employees' feelings about their work are related to their personality traits [18]. This article divided employee personality into internal controlling personality and external controlling personality, the employees with internal controlling personality pursuit of a sense of accomplishment and then improve their work behavior actively, however, the employees with external controlling personality like comply with the outside environment and the results of the event, they don't want to make a change to the result of the event.

Based on the above analysis, this article makes the following hypothesis:

$\mathrm{H} 2 \mathrm{a}$ : the internal controlling personality negatively affect the work values of comfort and safety;

$\mathrm{H} 2 \mathrm{~b}$ : the internal controlling personality positively affect the work values of ability and growth;

$\mathrm{H} 2 \mathrm{c}$ : the internal controlling personality positively affect the work values of status and independent;

$\mathrm{H} 2 \mathrm{~d}$ : the external controlling personality positively affect the work values of comfort and safety;

H2f: the external controlling personality negatively affect the work values of ability and growth; 
H2d: the external controlling personality negatively affect the work values of status and independent.

Organizational trust refers to a common belief that individuals or members of a group adhere to and are loyal to the agreed commitment and do not seek any other extra benefits [19]. The organizational trust of this article consists of three aspects: the trust of the individual to the organization, the trust of the individual to the colleague, and the trust of the individual to the superior. According to Thompson (2005) study, the employees with positive personality traits will take some measures to establish a good working relationship, including the relationship with colleagues and the relationship with the supervisor, to gain the success of the work [20]. The employees with the internal controlling personality, they are good at active thinking and pursuit of work quality, they are willing to accept suggestions and opinions from outside environment continuously, and then they will improve the work result, On the contrary, individuals with external controlling personality, the requirements for organizational trust are not high.

Based on the above analysis, this article makes the following hypothesis:

H3a: the internal controlling personality positively affect employees' trust in colleagues.

$\mathrm{H} 3 \mathrm{~b}$ : the internal controlling personality positively affect employees' trust in organizations.

$\mathrm{H} 3 \mathrm{c}$ : the internal controlling personality positively affect employees' trust in superior.

H3d: the external controlling personality negatively affect employees' trust in colleagues.

H3f: the external controlling personality negatively affect the employees' trust in organizations.

$\mathrm{H} 3 \mathrm{~g}$ : the external controlling personality negatively affect the employees' trust in superior.

\subsection{Work Values, Organizational Trust and Job Performance}

Fishbei (1975) believed that values has the function of motivation, it is the guidance of the behavior, he thought work values guidance the work as an inherent behavior standard of employees work, it affects the individual behavior, and then the job performance will be influenced [21]. Locke and Henne (1986) believe that individual work values determine their work objectives and then affect their job performance [22].

Different types of work values will produce different work behavior, the employees who pursuit of comfort and safety will reduce its job involvement, and they do not want in-depth exploration of the work, however, and the employees who pursuit of generation ability and growth, status and independent would increase their job involvement, they will take the initiative to improve yourself from all aspects and finish the work better.

Based on the above analysis, this article makes the following hypothesis:

H4a: the work values of comfort and safety negatively affect the improvement of job performance.

$\mathrm{H} 4 \mathrm{~b}$ : the work values of ability and growth positively affect the improvement of job performance.

$\mathrm{H} 4 \mathrm{c}$ : the work values of status and independent positively affect the improvement of job performance.

Shaw believes that the organizational function is mainly reflected in the four aspects: influencing organizational success, influencing team effectiveness, influencing organizational members' cooperation and influencing the trust of members of the organization [23]. Konovsky, Paugh (1944) believes that if the employee's organizational trust is high, it can promote the behavior of employees, thus reducing the friction between employees and the organization and ensuring the smooth work [24]. Dirk (2000) took the basketball team as a research sample and found that organizational trust was significantly correlated with team performance [25]. Mayer and Devis argue that in a highly trusted team atmosphere, members of the organization are free to exchange ideas and ideas, and turn the competition or conflict into a momentum for team development. Most scholars research on the relationship between the organizational trust and job performance conclusion is consistent, scholars agree that organizational trust has a positive effect on job performance, this article will divide organizational trust into the following parts: employees' trust in organizations, employees' trust in colleagues, and employees' trust in superior.

Based on the above analysis, this article makes the following hypothesis:

H5a: the employees' trust in colleagues positively affect the improvement of job performance. 
H5b: the employees' trust in organizations positively affect the improvement of job performance. H5c: the employees' trust in superior positively affect the improvement of job performance.

To sum up:

H6: work values play an intermediary role in the relationship between employee personality and job performance;

$\mathrm{H7}$ : organizational trust plays an intermediary role in the relationship between employee personality and job performance.

To sum up, conceptual framework in this paper is shown in Fig.1:

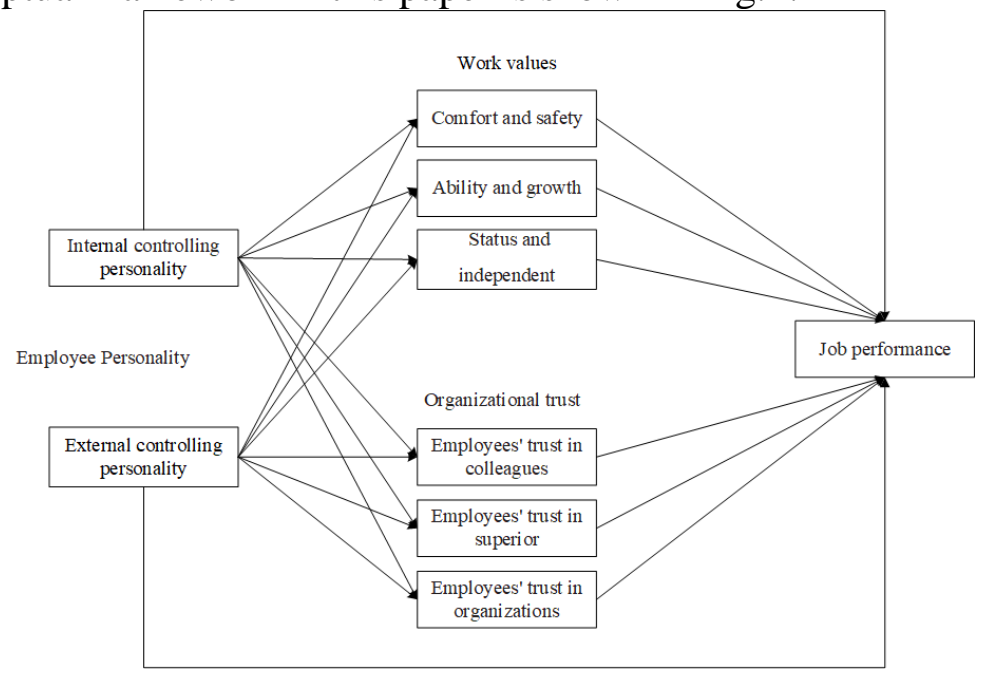

Fig. 1 Conceptual framework

\section{Conclusion}

Employees' personality has differences, different jobs require different personality traits of the incumbent, this makes the measurement of the employees' personality in the modern human resources management has the extremely important signification. From the effective use of personnel evaluation and selection theory, the correlation between employees' personality and job performance can be applied to improve the effectiveness of personnel evaluation and selection. From the perspective of human resources development, the study of the mediating effect of work values and organizational trust can help enterprises find the ways that meet the needs for self-realization of the employees. Then there is a need for making empirical research to confirm the relationship between employees' personality and job performance based on the work values and organizational trust.

\section{References}

[1]. R. R. Mccrae and P. T. Costa, "Comparison of EPI and psychoticism scales with measures of the five-factor model of personality," Personality and Individual Differences, vol. 6, pp. 587-597, 1985.

[2]. R. P. Tett and D. D. Burnett, "A Personality Trait-Based Interactionist Model of Job Performance," Journal of Applied Psychology, vol. 88, pp. 500-517, 2003.

[3]. P. G. Zimbardo, A. L. Weber and R. L. Johnson, psychology. (3rd ed.) Boston, MA: Allyn and Bacon, 2000.

[4]. G. W. Allport, "Personality: a psychological interpretation," American Journal of Sociology, vol. 13, pp. 48-50, 1937.

[5]. R. B. Cattell, "The description of personality: basic traits resolved into clusters," The Journal of Abnormal and Social Psychology, vol. 38, pp. 476-506, 1943.

[6]. J. B. Rotter, "Generalized expectancies for internal versus external control of reinforcement," Psychological Monographs, vol. 80, pp. 609-610, 1966. 
[7]. D. E. Super, "A life-span, life-space approach to career development," Journal of Vocational Behavior, vol. 16, pp. 129-148, 1980.

[8]. J. Yu, "vocational guidance of the important frame of reference- work values," education and career, pp. 28 and 29, 2001. (In Chinese)

[9]. P. J. Manhardt, "JOB ORIENTATION OF MALE AND FEMALE COLLEGE GRADUATES IN BUSINESS," Personnel Psychology, vol. 25, pp. 361-368, 1972.

[10]. S. L. Robinson, "Trust and Breach of the Psychological Contract," Administrative Science Quarterly, vol. 41, pp. 574-599, 1996.

[11]. M. R. Barrick and M. K. Mount, "THE BIG FIVE PERSONALITY DIMENSIONS AND JOB PERFORMANCE: A META-ANALYSIS," Personnel Psychology, vol. 44, pp. 1-26, 1991.

[12]. H. M. Lefcourt, "Internal versus external control of reinforcement: a review," Psychological Bulletin, vol. 65, pp. 206, 1966.

[13]. H. M. Lefcourt, "Recent developments in the study of locus of control," Prog Exp Pers Res, vol. 6, pp. 1-39, 1972.

[14]. N. Huo, C.P. Li, "research progress and prospect of work values" psychological science progress, vol. 17, pp. 795-801, 2009. (In Chinese)

[15]. U. Raja, G. Johns, and F. Ntalianis, "The Impact of Personality on Psychological Contracts," Academy of Management Journal, vol. 47, pp. 350-367, 2004.

[16]. P. T. Costa and R. R. Mccrae, "The 5-Factor Model of Personality and Its Relevance to Personality-Disorders," 1992.

[17]. A. Furnham and A. Mcclelland, "What Men Want in a Woman: Personality Is More Important than Academic Record or Athleticism," Psychology, vol. 06, pp. 942-947, 2015.

[18]. B. Schneider and H. P. Dachler, "A note on the stability of the Job Descriptive Index," Journal of Applied Psychology, vol. 63, pp. 650-653, 1978.

[19]. L. L. Cummings and P. Bromiley, "The Organizational Trust Inventory (OTI): Development and Validation," $\mathrm{Nj} \&$ Trust, 1996.

[20]. J. A. Thompson, "Proactive Personality and Job Performance: A Social Capital Perspective," Journal of Applied Psychology, vol. 90, pp. 1011-1017, 2005.

[21]. M. Fishbein and I. Ajzen, "Belief, Attitude, Intention and Behaviour: an introduction to theory and research," Philosophy \& Rhetoric, vol. 41, pp. 842-844, 1975.

[22]. J. Landau and T. H. Hammer, "Clerical Employees' Perceptions of Intraorganizational Career Opportunities," The Academy of Management Journal, vol. 29, pp. 385-404, 1986.

[23]. R. B. Shaw, "Trust in the balance: building successful organizations on results, integrity, and concerns," Psychiatric Rehabilitation Journal, vol. 7, pp. 220-221, 1999.

[24]. M. A. Konovsky and S. D. Pugh, "Citizenship Behavior and Social Exchange," The Academy of Management Journal, vol. 37, pp. 656-669, 1994.

[25]. K. T. Dirks, "Trust in Leadership and Team Performance: Evidence From NCAA Basketball," Journal of Applied Psychology, vol. 85, pp. 1004-1012, 2000.

[26]. R. C. Mayer, J. H. Davis and F. D. Schoorman, "An Integrative Model of Organizational Trust," The Academy of Management Review, vol. 20, pp. 709-734, 1995. 